\title{
拡幅を伴う直線流路の河床変動 1 次元解析 \\ ONE DIMENSIONAL ALALYSIS ON BED EVOLUTION \\ WITH BANK EROSION OF A STRAIGHT CHANNEL
}

\author{
中西哲 ${ }^{1} \cdot$ 長谷川和義 ${ }^{2} \cdot$ 高橋圭吾 $^{3}$ \\ Satoru NAKANISHI, Kazuyoshi HASEGAWA, Keigo TAKAHASHI
}

${ }^{1}$ 学生員 工修 北海道大学大学院 工学研究科（T 060-0082 北海道札幌市北区北 13 条西 8)

2 正会員 工博 北海道大学大学院 工学研究科 (同上)

非会員 北海道大学工学部 土木工学科（同上）

\begin{abstract}
This research focuses on relationship between river bank erosion and river bed longitudinal profile of a straight channel. Firstly, we constructed one-dimensional model of river bed deformation with bank erosion due to shear stress. To use this model, the diffusion equation with an advection phase was drawn. Secondary, we investigated the interaction between river bed profile and river width, through movable-bed experiments . As a result of the 1-D diffusion equation and the experiments, the following were found. (1) The aspect ratio $h / B$ is important parameter for longitudinal plofile with bank erosion. (2) As the aspect ratio is related to coefficient of advection phase of the diffusion equation, we can explain that the aspect rasio has close relevance to sediment transport considering geographical condition.
\end{abstract}

Key words: bank erosion, 1-D analysis, river-bed longitudinal profile, movable-bed model test

\section{1.はじめに}

河川がどのような変遷をたどり, 現在の様相を呈 しているかを知ることは河川の総合的な維持管理の 点で重要な問題である.しかしながら, それに対する 明確な回答を得ることは容易ではない。度重なる河 川改修や流域の開発などの人為的インパクトによっ て常に河川を取り巻く環境が変化し続けてきた結果, 幾多の要因が絡み合い問題が複雑化してきたからで ある.この問題に取り組むには長期的視野に立った 検証が必要である。.また河川環境を劇的に変化させ る人工化 (人工化指標, インプット)に対してどうの ように河川が変貌するのか(変貌指標, アウトプッ 卜）を把握することが必要となる.そこで本研究では その一つとして河川環境が変化することによって側 岸浸食が顕著となる状況を想定し, 側岸侵食と河床 縦断形の相互作用に関する問題を取り上げることと した。

側岸侵食は河道を維持・管理する点で大変重要な 問題である. その為側岸侵食の研究は古くから行わ れてきた. 平野 ${ }^{11}$ は土粒子に作用する力学的機構から
1 次元解析を行い, 安定横断形状の検討をした.さら に長谷川 ${ }^{2)}$ は非平衡性を土粒子に考慮し, せん断力の 関数で表される側岸侵食量式を導いている.福岡・山 坂 ${ }^{3)}$ はそれまで水路の斜面部と河床部を区分し計算し ていたものを境界に作用するせん断力を詳細に検討 することにより直線流路の拡幅現象に関する検討を 行っている。このように側岸侵食に関する研究は 多々あるのだが側岸侵食と河床縦断形状の相互作用 について述べられた研究はまだ少ない.

後藤・北村・辻本 $\left.{ }^{4}\right)$ は上下流端の境界条件が劇的に 変化する場合を想定し, その場合の側岸侵食と縦断 形変化の相互作用に関する解明を行っている. しか し, 後藤らのモデルでは河床低下に起因する側岸侵 食のみを扱っており，拡幅を伴う縌断形変化全般に 対し扱うことはできない，流路の拡幅と河床縦断形 の相互作用を解明するにはより一般性の高いモデル の開発が必要である.

本研究では以上のことを鑑み，側岸侵食を低水路 部のせん断力で評価できるモデルを開発し，そのモ デルから得られる2次元河床変動式を芦田 ${ }^{5)}$ と同様に 線形拡散方程式に帰着させた。またその拡散方程式 


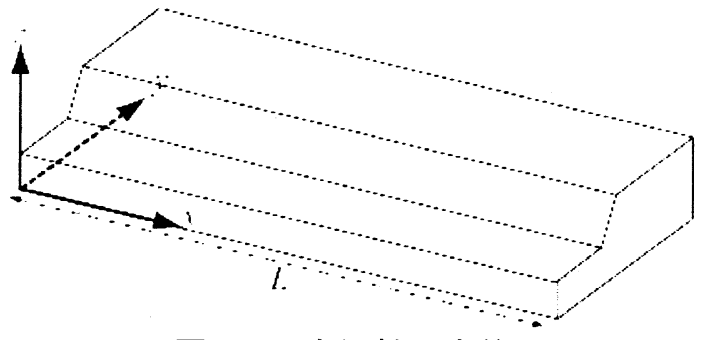

図-1 座標軸の定義

の解析と室内実験とを比較を行うことにより理論の 整合性を検討した。

\section{2. 理論式}

ここでは，側岸侵食による拡幅を伴う一次元河床 変動の解析を容易にするために線形拡散方程式に帰 着させる形で導く. 河床縦断形および河床横断面の 定義をそれぞれ図ー 1 , 図一2に示す. 縦断方向座標 軸 $x$ は上流からの距離であり, 横断方向座標軸 $y$ は片 側断面の右岸からの距離である。横断形は片側のみ 侵食が発生する断面とした. $z_{b}, H_{m}$ はそれぞれ基準面 からの河床高, 側岸天端高. $h, H$ はそれぞれ水深, 水 面より上部の天端高である. また横断方向の平均河 床高を $\bar{z}_{b}$ とし, 台形で表される水路の側岸部と低水 路部との境界を $B_{1}$ とした。

\section{（1）側岸侵食を考慮した 1 次元流砂連続式}

側岸侵食を考慮した 1 次元の流砂連続式を導くに は, 2 次元の流砂連続式を横断方向に積分し求める. まず, 2 次元の流砂連続式は以下のように表される.

$$
\frac{\partial z_{b}}{\partial t}+\frac{1}{1-\lambda}\left(\frac{\partial q_{b x}}{\partial x}+\frac{\partial q_{b y}}{\partial y}\right)=r
$$

ここで, $z_{b}$ は河床高， $\lambda$ は河床材料の空隙率， $q_{b x}$ $q_{b y}$ はそれぞれ $x, y$ 方向の単位幅流砂量である. $r$ は 側岸からの流砂の供給量強度を表す. 側岸侵食に起 因寸る土砂の供給量は水際が図中の $B$ から $B$ 'に移動 する,つまり侵食が図ー1の実線から破線に進行した と寸ると同図の斜線部に他ならない。この体積の土 砂が崩落し, 水流によって拡散され横断方向に一様 に降り積もるとする.このことを考慮すると $r$ は図一 2中における斜線部の単位長さあたりの体積であるか ら以下の式で表すことができる.

$$
r=\left(1-\lambda_{H}\right) \frac{H}{B} \frac{\partial B}{\partial t}
$$

ここで， $\lambda_{H}$ は河岸を構成する材料の空隙率.

式(1)を横断方向, つまり $y$ 方向に積分し断面平均 をとり, 式(2)を代入すると以下の式が導かれる.

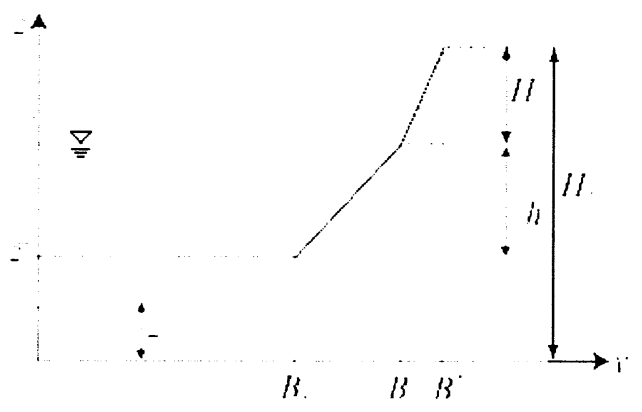

図-2 横断面の定義

$$
B \frac{\partial \bar{z}_{b}}{\partial t}-h \frac{\partial B}{\partial t}+\frac{1}{1-\lambda}\left[B \frac{\partial \bar{q}_{b x}}{\partial x}\right.
$$

$$
\left.+\left\{\bar{q}_{b x}-q_{b x}(B)\right\} \frac{\partial B}{\partial x}+q_{b y}(B)\right]=H \frac{\partial B}{\partial t} \frac{1-\lambda_{H}}{1-\lambda}
$$

ここで, 各パラメータの上部に付けられたバーは 各量の断面平均を表す. $q_{b x}(B), q_{b y}(B)$ はそれぞれ図一 2中のB地点における縦断, 横断方向の単位幅流砂量.

式 (3)を簡略化するために河床および側岸材料空隙 率を等しいとし，さらに水際における流砂量をせん 断力との兼ね合いから 0 とする. また長谷川 $\left.{ }^{2}\right)$ にる と側岸の時間変化と流砂量との関係は以下の式で表 される.

$$
\frac{\partial B}{\partial t}=\frac{-q_{b y}\left(B_{1}\right)}{(1-\lambda)(h+H)}
$$

以上の条件を用いると式(3) は次のようになる.

$$
\frac{\partial \bar{z}_{b}}{\partial t}+\frac{1}{1-\lambda}\left\{\frac{\partial \bar{b}_{b x}}{\partial x}+\frac{\bar{q}_{b x}}{B} \frac{\partial B}{\partial x}+\frac{1}{B} q_{b y}\left(B_{1}\right)\right\}=0
$$

式(4), (5) から河川の繸断形変化に対して側岸の天 端高は直接影響を及ぼさないが，川幅の時間変化つ まり側岸の侵食速度に対しては支配パラメータの一 つになることが分かる.側岸侵食に対して水深 $h か ゙$ 同 一だとすると側岸天端高 $H$ が高くなるにつれて側岸 侵食速度が遅くなる式となっている. なお以降, 断面 平均を表すバーを省略する。

\section{(2) 拡散方程式の誘導}

ここでは式(5)を拡散型の方程式へと帰着させる. そのためには拡散方程式を構成要素である河床縦断 勾配 $\partial z_{b} / \partial x$ に着目しつつ, 式を連立させパラメー タを減少させる必要がある.

まず運動方程式として局所等流が成り立ち, かつ 水面勾配の縦断方向変化が河床のそれと比較して無 視できるほど小さいと仮定する。エネルギー勾配は Manning 式から導いた. その結果, 無次元せん断力 $\tau_{*}$ は河床勾配を代入することによって求められる．縦 
断方向の流砂量式には Meyer-Peter Muller 式を, 横断 方向流砂量式は長谷川の式6)採用したが, 長谷川の 式を用いる際に現象を簡略した形で捉えるため底面 近傍の 2 次流が無視できるほど小さいと仮定し, 式 （6）に表されるようにその影響による項を省略する形 とした.

$$
q_{b y}\left(B_{1}\right)=-\tan \beta_{k} \sqrt{\frac{\tau_{* c}}{\mu_{s} \mu_{k} \tau_{*}}} q_{b x}
$$

ここで， $\tau_{* c}$ は限界無次元せん断力, $\tan \beta_{k}$ は河床の 横断方向勾配でありここでは $\beta_{k}$ を側岸水際の水中安 息角を表している， $\mu_{s}, \mu_{k}$ はそれぞれ静止および動摩 擦係数.

以上の式を用いて式(5)を拡散方程式一と導くのだ がその過程において以下の条件を用いる.

(1) $\tau_{* c}$ が $\tau_{*}$ より十分小さいと仮定することにより，2項 定理を用いた近似が可能である.

(2)川幅の縦断方向変化は無視できるほど小さい.

(3)式(8)のような近似的取り扱いを行う.

$$
\begin{gathered}
\left(\tau_{*}-\tau_{* c}\right)^{\alpha} \approx \tau_{*}^{\alpha}\left(1-\alpha \frac{\tau_{* c}}{\tau_{*}}\right) \\
\left(\frac{\partial z_{b}}{\partial x}\right)^{1 / 20} \approx\left(\frac{\partial z_{b}}{\partial x}\right)^{0}=1
\end{gathered}
$$

結果，式(5)は以下の通りになる.

$$
\begin{gathered}
\frac{\partial z_{b}}{\partial t}=K_{1} \frac{\partial^{2} z_{b}}{\partial x^{2}}-K_{2} \frac{\partial z_{b}}{\partial x} \\
K_{1}=\frac{42 \sqrt{g}}{5(1-\lambda)_{s}}\left(\frac{n Q}{B}\right)^{9 / 10}\left(1-\frac{1}{2} \frac{\tau_{* c}}{\tau_{*}}\right) \\
K_{2}=\frac{8 h}{(1-\lambda) B} \tan \beta_{k} \sqrt{\frac{g d \tau_{* c}}{s \mu_{s} \mu_{k}}}\left(1-\frac{3}{2} \frac{\tau_{* c}}{\tau_{*}}\right)
\end{gathered}
$$

式(9)の $K_{1}$ および $K_{2}$ を定数として扱うことにより， $z_{b}$ の $x$ に対する一階微分項を含んだ線形拡散方程式が 導かれた.この点が後藤らの扱いと本研究とが大き く違う点である. 一階微分項の係数 $K_{2}$ は側岸侵食の 拡幅速度式から導かれたものである. そのため侵食 の促進される状況ではその值が大きくなる．逆に河 床が安定し側岸侵食が止まると $K_{2}$ は 0 となる.この ことより $K_{2}$ は川幅水深比 $h / B$ に依存することが予想 される.

\section{（3） 拡散方程式の解}

ここではより汎用性を高めるため上下流端での境界 条件を設定する．上下流端の境界条件をそれぞれ
$z_{U}(t), z_{D}(t)$ とし, 初期条件を $\varphi(x)$ とすると拡散方程式 の解は以下のようになる.

$$
\begin{aligned}
z_{b}(x, t) & =\exp \left\{\frac{K_{2}}{2 K_{1}}\left(x-\frac{K_{2} t}{2}\right)\right\} \\
& \times \frac{2}{L} \sum_{n=1}^{\infty} \sin \lambda_{n} x\left[K _ { 1 } \lambda _ { n } \int _ { 0 } ^ { t } \left[e ^ { - \lambda _ { n } ^ { 2 } K _ { 1 } ( t - \tau ) } \left\{z_{U}^{\prime}(\tau)\right.\right.\right. \\
& \left.\left.\left.-(-1)^{n} z_{D}^{\prime}(\tau)\right\}\right] d \tau+e^{-\lambda_{n}^{2} K_{1} t} \int_{0}^{L} \phi(\xi) \sin \lambda_{n} \xi d \xi\right]
\end{aligned}
$$

ここで, $\lambda_{n}$ は固有值を表し, $z_{U}^{\prime}(t), z_{D}^{\prime}(t)$ および $\phi(x)$ は境界条件ならびに初期条件から派生するものでそ れぞれ次の通りである.

$$
\begin{gathered}
\lambda_{n}=\frac{n \pi}{L} \\
z_{U}^{\prime}(t)=z_{U}(t) \exp \left\{\frac{K_{2}}{2 K_{1}} \frac{K_{2} t}{2}\right\} \\
z_{D}^{\prime}(t)=z_{D}(t) \exp \left\{\frac{K_{2}}{2 K_{1}}\left(\frac{K_{2} t}{2}-L\right)\right\} \\
\phi(x)=\exp \left\{-\frac{K_{2}}{2 K_{1}} x\right\} \varphi(x)
\end{gathered}
$$

以上の式を実験值と比較・検証することで現象の 機構を把握する.

\section{3. 移動床実験}

\section{（1） 実験概要}

実験に用いた水路は水路長 $15 \mathrm{~m}$ ，幅 $0.8 \mathrm{~m}$ ，側壁高 さ $0.2 \mathrm{~m}$ の可変勾配水路である. この水路の上流端か ら $1 \mathrm{~m}$ 下流の位置から下流端から $3 \mathrm{~m}$ 上流まで区間, 実 長 $L=11 \mathrm{~m}$ に砂を敷き詰めた．実験に用いた土砂はほ ぼ均一の平均粒径 $0.6 \mathrm{~mm}$ である硅砂 4 号を使用した. 今回の実験では図一 1,2 に示されるような片側のみ が侵食する水路を作成した，その際の初期低水路幅

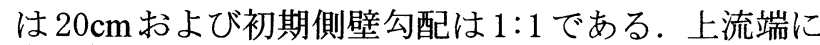
おいて給砂は行わず，下流端は堰を設けて常に等流 が保たれる条件とした。

計測にはレーザー変位計を用い, 縦断方向に $50 \mathrm{~cm}$ 毎に河床横断形を計測した。計測時間は通水開始か ら 1 分, 5 分, 15 分, 30 分, 1 時間の各時間に計測を 行った. なお計測中は通水を停止した. その他の実験 条件を表ー1に示す. Case1, Case2では勾配を変化 させ河床縦断形状に対してどのような変化を与える かを,さらにCase3では河岸天端高を変化させるかに より側岸の侵食速度の変化に対する実験を行った。 
表 -1 実験の水理条件

\begin{tabular}{|c|c|c|c|c|}
\hline & \multirow{2}{*}{$\begin{array}{c}\text { 流量 } \\
\left(\mathrm{m}^{3} / \mathrm{sec}\right)\end{array}$} & $\begin{array}{c}\text { 低水路幅 } \\
(\mathrm{cm})\end{array}$ & $\begin{array}{c}\text { 側岸天端高 } \\
(\mathrm{cm})\end{array}$ & 勾配 \\
\hline \multirow{2nnny}{*}{ Case1 } & \multirow{3}{*}{6} & \multirow{2}{*}{20} & 10.5 & $1 / 200$ \\
\cline { 1 - 3 } \cline { 4 - 5 } Case2 & & & 10.5 & $1 / 500$ \\
\cline { 1 - 3 } Case3 & & & 12.5 & $1 / 200$ \\
\hline
\end{tabular}

\section{（2）実験結果}

写真－1は，Case1 の通水開始から 1 時間後の様子 を下流から上流に向かって撮影したものである。低 水路部に明瞭な Dune の発達をとらえることができ る. 初期河床勾配が緩やかなため掃流力の小さい Case2 の実験では，河床波は Dune が発生した後，交 互砂州の発達が確認された. また拡幅の様子は, 側岸 天端にクラックテンションが発生した後崩落が起き るが, 縦断方向に連続的ではなく間欠的に生じた. 崩 落の局所的崩落は間欠的であるのだが，写真からみ て分かるとおり縦断方向にはほぼ一様に侵食され, 上下流端を除くと川幅の縦断方向変化はほとんど見 られなかった。

図一3に各Caseにおける河床高の時間変化を示す. ここで $z_{f}$ は初期河床高を表し, 河床高は低水路部河 床高の横断方向平均をとったものである. 傾向とし てはどのCaseにおいても堆積する傾向となった。 Case1 と Case3 に比べて勾配の緩やかな Case2 では堆 積が抑えられている. Case1 と 3 では縦断形状に大き な違いは見られなかった。図一 4 に各 Caseにおける 横断形の縌断方向平均を示す. どの Caseにおいても ある一点を境に堆積領域と浸食領域が区分されてい る. Case2, Case3 の結果はCase1 の結果と比較して侵 食速度が遅いことが分かる．前者は河床勾配が緩や かなためせん断力が小さいためであり, 後者は天端 高の高低による差である. 図ー3，4 の両図の結果か ら側岸からの土砂供給は低水路の縦断形状に影響を 及ぼすと考えられる。

侵食速度に対して側岸の天端高がどのように影響 を及ぼすかを見るために図ー5に川幅の時間変化を 示す. 図から側岸天端高が低いCase 1 の侵食速度が速 くなっており，これは福岡・山坂 ${ }^{3}$ の実験と同様の結 果となった。侵食過程は一般的に次のように表され $る^{7)}$.

(1) 側岸付近の洗掘による水際の後退

(2) 側岸を形成する土砂の崩落

(3) 崩落土砂の流送

この過程を繰り返すことにより側岸侵食は進行する. 式(10)に表されるように, 同一水理条件下では崩落 した土砂を水際から低水路に運搬する能力もまた同 一になる. そのため, Case3ではCase1 と比較して天

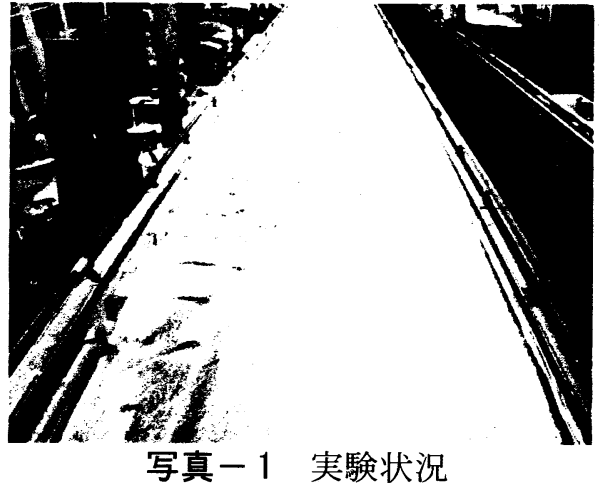

端高が高いため, 1回の崩落による土砂供給量が多く その土砂をを水際から運搬するために費や寸時間が 多くかかり侵食速度が遅くなったと考えられる。

\section{4. 比較・考察}

\section{（1）側岸侵食速度}

ここでは理論式に用いた侵食速度式と実験值を比 較することにより整合性を検証する。側岸侵食は前 述の通り横断方向流砂量に支配される. そのため, そ れぞれの横断方向流砂量を比較することにした．理 論から得られる横断方向流砂量は式 (6) を用い, 実験 值は実測から得られた侵食速度を式(4)に代入するこ とによって求めた。 その結果を図一6に示す. 図から 実験值より理論值が大きくなる傾向となった。そのの 誤差は流砂量が小さくなるにつれて，つまり時間が 経つにつれて大きくなっている．若干のずれがある もののオーダーが極端に違うものが少ない．本研究 では無次元せん断力を求める際，エネルギー勾配に 初期河床勾配を用いたいわば概略值である。福岡ら によると拡幅現象を解析する際には側岸付近のせん 断力を詳細に検討する必要があるとされているが, 今回は低水路のせん断力を直接側岸侵食に結びつけ ている．そのため河床勾配が初期と異なるにつれて 理論值と実験值との誤差が生じることが予想される. そのことを考慮すると図ー6に示された結果は比較 的良好だと考えられる.

\section{（2）河床縦断形状}

式(9)を用いて河床縦断形状の時間変化について考 察する. 前述の通り側岸侵食速度式が有効であると すると，それから派生する式(9)における $K_{2}$ の評価が 必要となる. そこで $K_{1}$ をおおよその值で固定し $K_{2}$ を 変化させることによって河床縌断形の時間変化を理 論式から表現できるかどうか検証した。なお境界条 件には実験で計測された上下流における河床高の時 間変化に指数関数をあてはめることによって与えて 


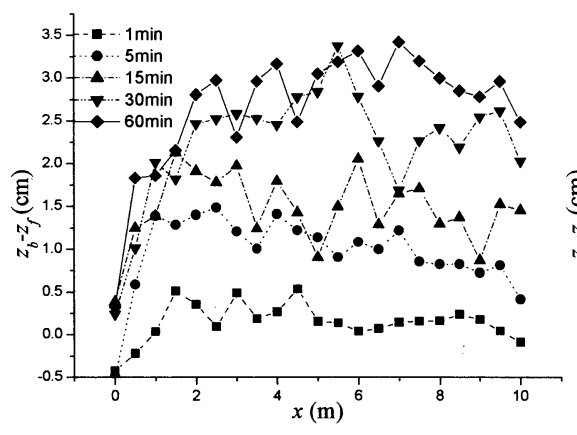

(a) Case 1

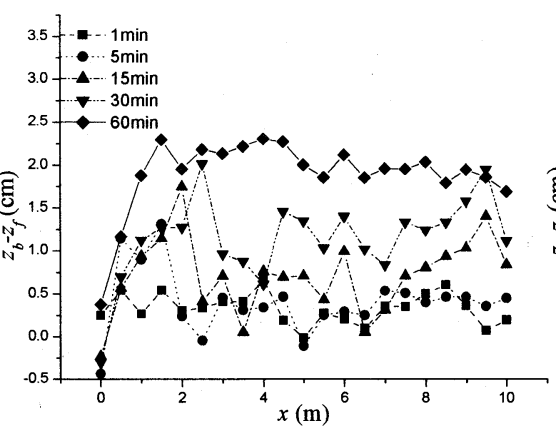

(b) Case 2

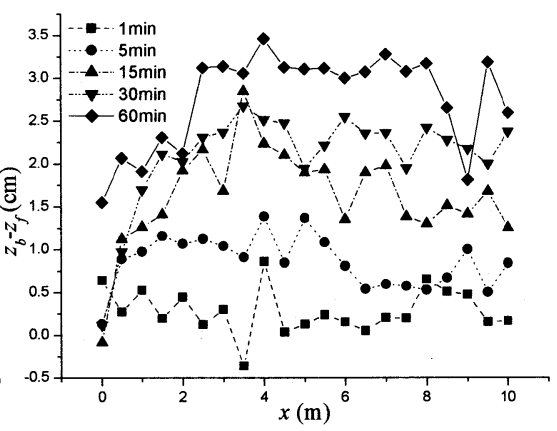

(c) Case 3

図一 3 各 Caseにおける河床縦断形の時間変化

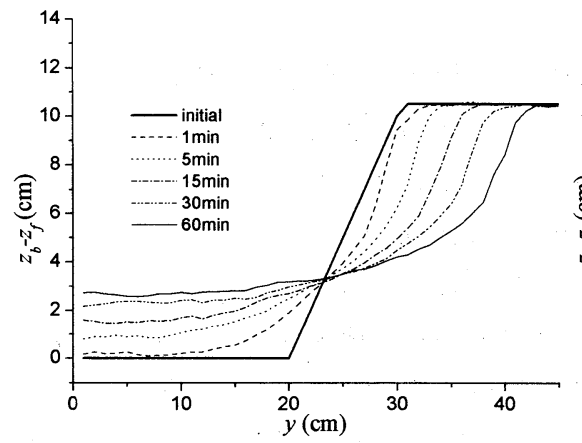

(a) Case1

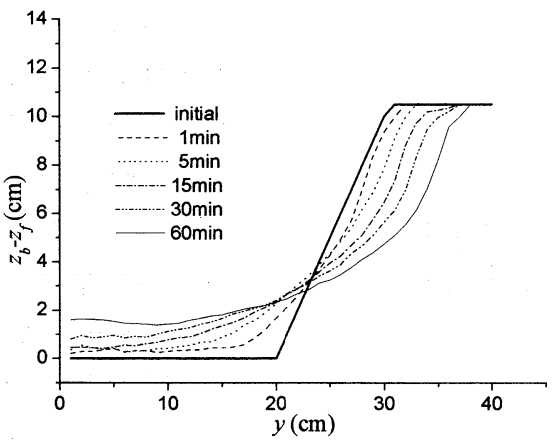

(b) Case2

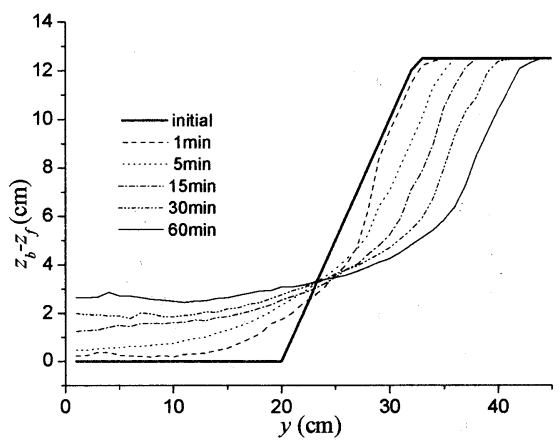

(c) Case 3

図一 4 各 Caseにおける横断形状の時間変化

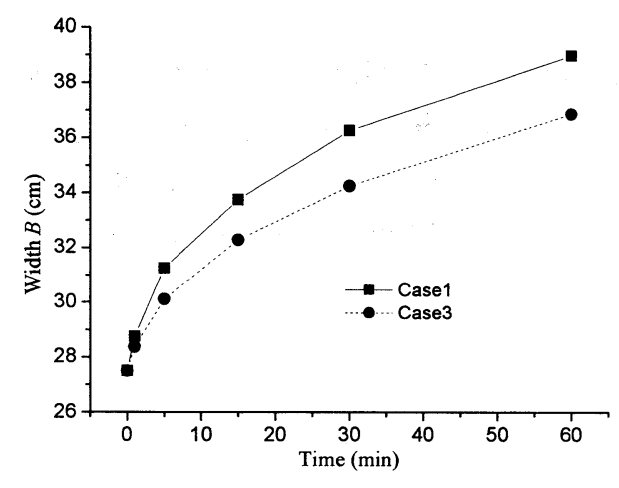

図－5 Case1，3の川幅の時閒変化

いる. 実際は $K_{1}$ も時間的に変化すべきではあるのだ が，便宜上一定值とした。

図－７は各 Case において $K_{1}=0.03\left(\mathrm{~m}^{2} / \mathrm{s}\right)$ と固定し， $K_{2}$ を変化させもつとも適当な值を求めたものである. 図中に示される $K_{2}(\mathrm{~m} / \mathrm{s})$ は時間的に異なる值となり， その值は時間が経つにつれて減少する傾向となった． また理論值より求めた河床縦断形は上に凸となった.

式(11)より係数 $K_{2}$ を支配しているパラメータは川 幅水深比 $h / B$ である. 側岸侵食が進行すると川幅は増 加し水深は減少するので，このパラメータは明らか に減少する.このことより拡幅が顕著な河道の河床 縦断形に対して重要なパラメータの一つとなること が分かる.また, 流路拡幅が遅いほど同時刻における

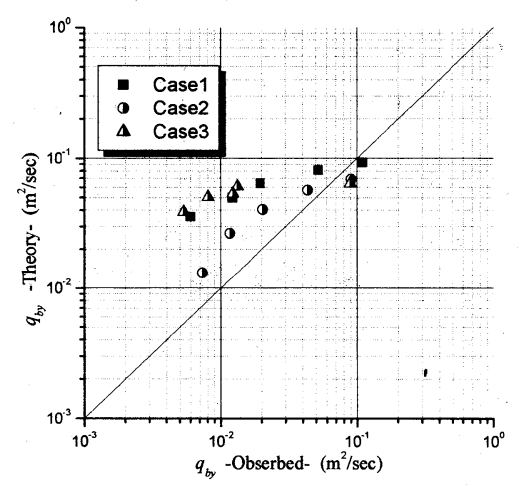

図－6 斜面部における横断方向流砂量の理論值と 実験值の比較

$K_{2}$ の值は大きくなるのだが, 今回の実験ではCase3の ように必ずしもそのような值を示さなかった，その 原因は側岸の天端高違いが $2 \mathrm{~cm}$ と全体のスケールと 比較して小さい值であり，そのため $K_{2}$ の違いを明瞭 に示すことができなかった可能性がある.このこと は今後の課題であろう。

また，図一7を見ると上に凸の河床形状を形成しそ の形を保ったまま下流へと流れている。このことは 実際の現象における土砂のマスムーブメントに相当 するものと考えられる. 実際の現象では大雨等によ り大量の土砂が河川へと流入し，一時的な土砂の過 剰な堆積が生じ，その後ゆっくりと河ロへと流下す るのだが，本研究結果はこの事象とよく類似した結 


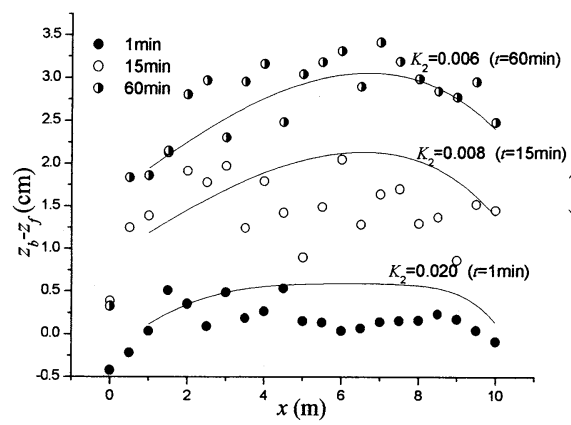

(a) Case 1

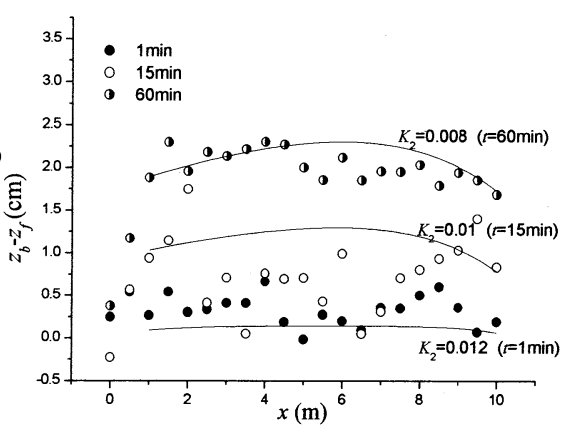

(b) Case 2

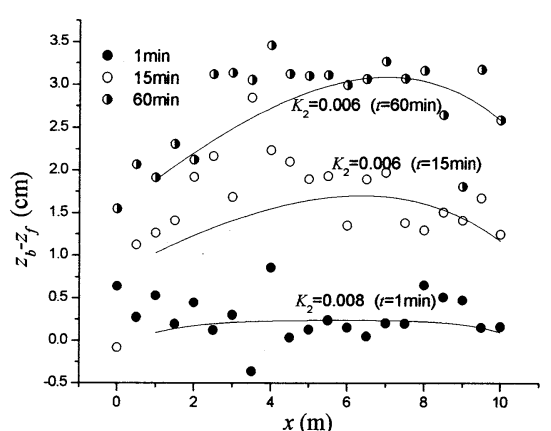

(c) Case 3

図-7 河床維断形状の理論值と実験值の比較

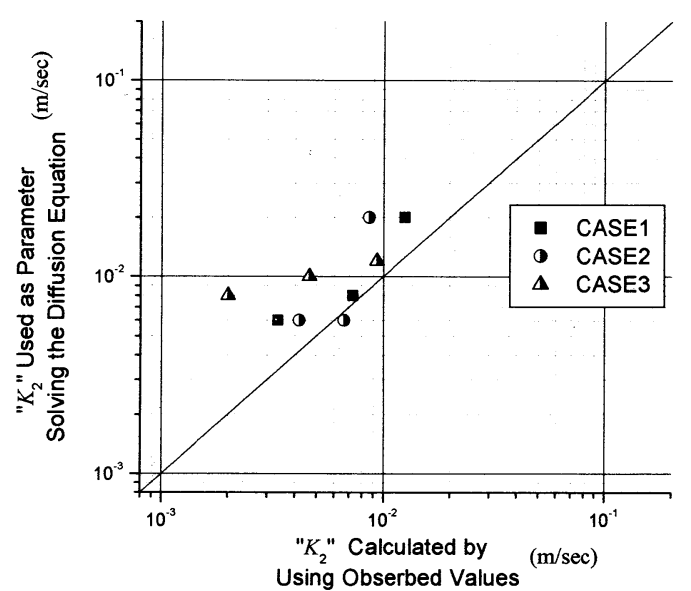

図ー8 縦断形に用いた $K_{2}$ と 水理条件から求めた $K_{2}$ の比較

果となった。土砂動態を実際の地形的要因に当ては める. 式(9)における $K_{2}$ の役割は $\partial z_{b} / \partial x$ が移流項と なることから河床形状を下流へと伝える速度である. $K_{2}$ が大きくなる谷地形の場合は河床の伝播は速くな り，逆に下流部といった $K_{2}$ が小さくなる場合は伝播 は遅くなる. 以上より, 式(9) は土砂動態の実際の現 象をうまく表現している.

図ー8に図ー7で用いた $K_{2}$ と式(11)に水理量を代 入し得られる $K_{2}$ との比較した図を示す.おおよそ一 致しているととらえることができるが，若干のずれ に対しての考察として $K_{1}$ を一定としたことが原因の 一つであろう．拡散係数 $K_{1}$ は川幅, せん断力により 支配され, 時間とともに変化する. そのため詳細な検 討が必要となるが本研究では便宜上一定值としたが, そのことを考慮すると比較的よい結果になったとい える。

\section{5. おわりに}

本研究で得られた知見を以下に示す.

(1) 流砂連続式に横断方向流砂量で表される流路拡幅 式を用いることにより，一階の空間微分項を含む
形が導かれた。

(2) 拡幅速度に関する実験值と理論值を比較したとこ ろ, 理論值が大きくなる傾向となったが比較的有 効な值となった。この誤差に関しては理論值にお けるせん断力の過大評価が原因だと考えられる.

(3) $K_{2}$ は時間とともに減少し，また $K_{2}$ のパラメータで ある $h / B$ も流路拡幅に伴い減少する. そのため $h / B$ は河床縦断形にとって重要なパラメータである.

(4) $K_{2}$ はいわゆる移流項の係数であり, 河床形状を下 流に伝播する速度を表す.土砂動態を実際の地形 的要因に当てはめると実現象に似た現象となる.

今後の展開として，実際の現象に近い実験並びに 解析を行う必要があると考えている．例を挙げると 水路のショートカット等による河床縦断形への影響 を想定して, 今回と同様に現象の機構を把握できれ ばと考えている.

\section{参考文献}

1) 平野宗夫 : 拡幅を伴う流路変動について, 土木学会論 文報告集, No. 210 号, pp. 13-20, 1973. 12 .

2) 長谷川和義 : 非平衡性を考慮した側岸侵食量式に関する 研究, 土木学会論文報告集, No. 316 号, pp. 37-50, 1981. 12.

3) 福岡捷二・山坂昌成: なめらかな横断面形状を持つ直線 流路のせん断力分布と拡幅過程の解析, 土木学会論文 集, No. 351 号, pp. 87-96, 1984. 11.

4) 後藤孝臣・北村忠紀・辻本哲朗 : 上・下流境界条件の変 化による直線砂砅流路の側岸侵食を伴う河床低下に関す る研究, 土木学会論文集, No. 684 号, pp. 35-46, 2001. 8.

5) 芦田和男: 河床変動に関する研究, 京大防災研究所年報, 第 12 号 B, pp. 437-447, 1969.

6) 長谷川和義: 沖積蛇行の平面および河床形状と流れに関 する水理学的研究, 北海道大学学位論文, 1983

7) 藤田裕一郎 : 直線流路の側岸侵食機構, 京大防災研究所 年報，第 22 号 B-2, pp. 537-552，1979.4.

(2004.9. 30 受付) 